\title{
INTEGRAL WATER MANAGEMENT ON THE TERRITORY OF THE TOWN OF KRUŠEVAC
}

\author{
Ivan Filipović ${ }^{*}$, Ljiljana Stričević ${ }^{*}$ \\ "University of of Niš - Faculty of sciencies and mathematics, Niš
}

\begin{abstract}
Providing sufficient amount of quality water for the population is a primary goal of each community. Both lack and irrational management of such an important resource influenced actualization of this problem in Serbia, as well as the need to intensify the activities on preserving water resources through implementation of Directive on waters, brought by European Union, based on integral management of water resources. This work analyzes available water resources on the territory of the town of Kruševac from the aspect of integral water management, which implies consideration of the problem of optimal usage of water resources for the need of different users, as well as protection of water resources from pollution. Organized water supplying of the population of Kruševac with quality water, as the most important activity in water management, is partly realized by building by building reservoir "Ćelije", while ground waters are still used for supplying industrial plants. Besides providing sufficient amounts of water, adequate purification and waste water drainage from the settlements and industrial plants represent a big problem. This problem could be solved by increasing the number of households connected to sewage network and the amount of communal and industrial waste waters which are purified adequately, by constructing new and reconstructing the existing plants. Regular and adequate water supply of population and industry is an important matter, but it is equally important to preserve the rivers and underground springs from unpurified, used water loaded with harmful substances which can lead to disturbance of river eco-systems. The aim of this work is to point out the possibilities of more rational usage and more quality protection of water resources on the territory of Kruševac, which would more adequately coordinate economic and social development and principles of sustainable water management.
\end{abstract}

Key words: integral management, water resources, the town of Kruševac.

${ }^{1}$ Corresponding author: Lj. Stričević, University of Niš - Faculty of sciencies and mathematics, Višegradska 33, 18,000 Niš, Serbia; e-mail: 1jiljanastricevic@pmf.ni.ac.rs 


\section{Introduction}

The need for water both in the world and Serbia has been particularly present for the last few decades. Accelerated demographic growth, industrial production and intensive urbanization face mankind with big problems of providing sufficient amounts of water for the needs of population, agriculture and industry. Due to uneven time and spatial water distribution, which is in part conditioned by both global climate changes and irrational anthropogenic activities, about $80 \%$ of the world's population is exposed to a high risk from water shortage or sanitary defective water. Such a state of water resources requires a responsible action of the society in terms of the choice of the most rational and economic concept of the management of this important resource which will imply defining main factors of their degradation and implementation of adequate measures for their reparation and revitalization (Vorosmarty et al., 2010).

One of the most important documents in the area of water resources management is EU/WFD - Water Framework Directive, 2000/60/EC, adopted from the part of European Parliament and European Union Counsel. The main goal of the Framework Directive is to bring all the natural waters in "good state", that is, to provide good hydrological, chemical and ecologic state of waters based on the principles of sustainable management which does not endanger life environment (Marković, 2011). Each country - member of European Union or a country obliged to implement the Directive is required to make an integrated management plan for each river basin on its territory.

Integral water management should be seen as a continuous process realization of which would lead to a significant social and social-economic advancement on a certain territory. Modern water management requires a multidisciplinary approach to this problem, so as to reach conditions for rational water exploitation, planning and water management on a scientific and expert basis, avoiding conflict among interest groups, participation of population in planning and management, as well as strengthening of institutional, financial and other mechanisms by works (Gourbesville, 2008; Biswas, 2008; Vučijak, Ćerić, Silajdžić, Midžić Kurtagić, 2011; Van der Zaag, Savenije, 2014).

Integral water management in Serbia is based on the implementation of the Law on waters (Official Gazette of the Republic of Serbia, no. 30/10, 2010.), as well as on the implementation of the following key plan documents: The Strategy of water management on the territory of Serbia, The Plan for water management for the Danube basin, The Plans of water man- 
agement for water areas, as well as the plans which systemize the protection from harmful effects of waters.

By the law on waters, Integral water management is defined as a set of measures and activities directed to maintenance and development of water regime, providing the needed amounts of water of required quality for different purposes, protection of waters from pollution, and protection from harmful effect of waters. This law regulates the following more concrete questions: authorization, principles, territorial bases for water management (unique water region, water areas, melioration area), as well as plan documents for water management (Тодић, 2015).

This work will analyze an integral approach to water management on the territory of Kruševac, which implies the perception of the problem of optimal use of available water resources for the needs of different users and protection of water from pollution. A successful integral water management by the principles of sustainable development is not possible to realize if we do not dispose of adequate and reliable data and information on the waters and all the processes which take place there. To reach the given objective, in this study we have shown the total water potential on the territory of Kruševac of both surface and ground waters. Surface waters were analyzed from the aspect of their potentiality for the needs of water supply and hydro energy, while ground waters were principally analyzed from the aspect of water supply and the possibility of the usage of mineral and thermo-mineral waters.

For the available surface and ground waters, we have given guidelines for their optimal usage, as well as the guidelines for their excessive usage and pollution. Harmful effect of waters was also analyzed, represented by the risks from floods, as well as the quality and water protection.

We have also considered the need for adopting an appropriate legal and economic regulation, so as to create conditions for adequate implementation of integral management of water resources, in accordance with recommendations and activities in this field which were implemented in the countries of European Union.

\section{Research methodology}

Bearing in mind the aim of the research, comparative, statistical, as well as method of analysis and synthesis were used. For this study, we have used available literature from the field of integral water management, pub- 
lished both in the world and in Serbia. Apart from the available literature, we used the data from the appropriate administrative services - Statistical Office of the Republic of Serbia, Republic Hydro meteorological Service, republic and local institutions: Serbia waters, Institute for Health Protection Kruševac, Waterworks - Kruševac.

This study analyzes legal regulative of water management in Serbia. This regulative is based on the principles of integral water management in European Union.

\section{Available water resources}

On the territory of the town of Kruševac there are important surface and ground water resources. Among surface courses, we can single out the courses of the Zapadna Morava, Rasina and Ribarska River as the most important ones.

Table 1 shows basic characteristics of water regime of the rivers of Kruševac in the period 1950-2009 through discharge mean, minimal discharge of $95 \%$ provision and maximum annual discharge of $1 \%$ provision. The ratio between 100-year maximum discharge and minimum discharge of $95 \%$ provision of 758.20 on the Rasina in Bivolje point to a distinct flood character of the most of its tributaries.

Table 1 - Characteristic indicators of the water regime of Rasina district

\begin{tabular}{|l|c|c|c|c|c|c|c|}
\hline \multirow{2}{*}{ Station } & $\mathbf{Q}_{\text {god. }}$ & $\mathbf{q}_{\text {god. }}$ & $\mathbf{Q}_{\text {min.95\% }}$ & $\mathbf{q}_{\text {min.95\% }}$ & $\mathbf{Q}_{\text {max.1\% }}$ & $\mathbf{q}_{\text {max.1\% }}$ & $\mathbf{Q}_{\text {max.1\%\% }}: \mathbf{Q}_{\text {min.95\% }}$ \\
\cline { 2 - 8 } & $\mathbf{m}^{3} / \mathbf{s}$ & $\mathbf{1} / \mathbf{s} / \mathbf{k m}^{2}$ & $\mathbf{m}^{3} / \mathbf{s}$ & $\mathbf{1} / \mathbf{s} / \mathbf{k m}^{2}$ & $\mathbf{m}^{3} / \mathbf{s}$ & $\mathbf{1} / \mathbf{s} / \mathbf{k m}^{2}$ & \\
\hline Jasika & 105.2 & 7.15 & 11.97 & 0.81 & $1,651.93$ & 112.22 & 138.01 \\
\hline Bivolje & 7.62 & 7.95 & 0.46 & 0.44 & 348.77 & 364.06 & 758.20 \\
\hline
\end{tabular}

Source: Republički hidrometeorološki zavod

Water potential of surface waters of Kruševac is modest, considering the fact that specific profusion is around $7.15 \mathrm{l} / \mathrm{s} / \mathrm{km}^{2}$. The state on all the water courses of the analyzed territory is significantly more unfavorable if we consider time and spatial nonlinearity of average, low and high waters.

Water balance represents quantitative and qualitative ratio of available and needed quantities of surface and ground waters on a certain area in cer- 
tain time. Water balance analysis is important in hydrological research from the aspect of rational and practical usage of available waters. On the basis of understanding its components it is possible to determine measures for their improvement, especially from the aspect of water supply of the population and industry with healthy and quality water. Total quantity of precipitation which falls in the basin of the Zapadna Morava amounts to $749.60 \mathrm{~mm}$. Out of this quantity $223.44 \mathrm{~mm}$ or $30 \%$ outflows on the surface. The outflow is uneven during the year and in different seasons. The highest amount of precipitation outflows during spring months $-40.80 \%$, while the smallest outflows in autumn $-13.71 \%$, (about 3 times less than in spring).

Evaporation in the basin is high. Out of the total amount of precipitation $526.16 \mathrm{~mm}$ or $70 \%$ evaporates annually. The highest evaporation is in summer months $-34.17 \%$, the lowest in winter $-17.39 \%$. Out of the total amount of precipitation $628.08 \mathrm{~mm}$ infiltrates into soil, but only $16 \%$ out of the amount gets into water course, which implies unfavorable regime of nourishing water course with ground waters and the necessity of undertaking essential measures to improve such a state (Стричевић, 2015).

Apart from surface water courses, on the territory of Kruševac there are important ground water springs: phreatic ground water, artesian, sub-artesian and mineral springs. Ground waters are an important resource, firstly as possible water sources for water supplying of population and industry, while mineral waters can be used for health-medical purposes, as well as in tourism.

Phreatic ground water appears in alluvial pebbly and sandy sediments of the Zapadna and Južna Morava and their tributaries. Ground waters of alluvial springs of the Zapadna Morava and Rasina are used for the needs of Kruševac industry. Waters from the alluvial spring of the Rasina were used for the needs of factories "Župa" and "Trayal", their profusion was $4-17$ l/s. Waters of alluvial spring of the Zapadna Morava had been used for water supplying up to the construction of the reservoir "Ćelije", that is, building of water plant in the village of Majdevo in 1984. Some of these springs were activated again in 1998 for the needs of FAM factory, situated on the right bank of the Zapadna Morava.

In terrace layers of the Zapadna Morava and Rasina compact type of spring was formed and these springs are most often capped in drinking fountains. On the territory of the town of Kruševac such drinking fountains can be found in Stara čaršija, old part of the town (profusion of about 1 1/s), in Lazarica (0.5 l/s) and in Jug Bogdanova Street. All these drinking fountains were the main source of water supply for the population of Kruševac during 1930s (Stojadinović, 2004). 
Sub-artesian and artesian springs occur in Neogene, mostly Sarmatian aqueous layers the thickness of which amounts to $100-500 \mathrm{~m}$. The appearance of artesian spring in this territory was indicated as early as before World War 2, which was proved by drilling of a well $205 \mathrm{~m}$ deep in the yard of "Rasina" mill in 1937, as well as around the bluestone factory, today "Župa", in 1938. These wells provided water with maximum capacity of 1.30 1/s (Stojadinović, 2004). Drilling of artesian wells in Kruševac continued after World War 2, for the purpose of solving the problem of water supply to the town, which became present because of the town's dynamic development. Most of artesian wells are not active today, partly because of deterioration and decreased capacity, but also because the town is supplied with water from the reservoir "Ćelije".

Mineral springs represent a significant natural resource, appropriate for exploitation, development and affirmation of this area. Adequate research, as well as planned management of these springs could represent an adequate basis for the development of therapeutical, health and sports-touristic activities. Important mineral springs on the territory of Kruševac are as follows: Trebotin (cold, alkali - acidic, ferruginous-muriatic water), Buci (cold acidic water), Majdevo (cold mineral water), Sezemče (cold acidic water), Slatina (cold, mild mineral water), Lomnica (cold, alkali - acidic - muriatic water), Dvorane (cold, mild ferruginous acidic water), Čitluk (acidic water), Bela Voda (acidic, ferruginous, contains Selenium and Magnesium).

\section{Integral water management and discussion}

Basic aim of integral water management is accomplishing complete and adjusted water regime on a certain territory. This implies consideration for spatial layout and the quantity as well as quality of the waters on a certain territory, that is, in a certain period. On the basis of the above mentioned, we can conclude that integral water management implies ensuring sufficient amount of quality drinking water for public supply of the population, necessary amount of water of the appropriate quality for different economic needs, protection of human lives and material goods from the harmful effect of waters, as well as preserving good condition of the waters for the protection of water eco-systems.

To enable integral water management, it is necessary to adjust water management measures to spatial management measures and ensure fine status of surface and ground waters. 
Water supply of the population is a priority in relation to all the other forms of water exploitation, so it is necessary to determine required amounts of drinking water for this consumer category. Amounts of water needed for public supply in a certain period are defined on the basis of demographic indicators, projections of the degree of connectivity to the system and projected specific consumption.

Water supplying for the population of Kruševac before the construction of reservoir "Ćelije" was oriented to ground waters from alluvial plains of the rivers of Zapadna Morava and Rasina. Due to constant growth of the number of inhabitants and industrial growth, there was a need to find new springs for water supplying.

Construction of water reservoir "Ćelije" was started in 1972 as a multipurpose reservoir (water regulation, flood protection, improvement of low waters, and so on), but its primary function was stopping drifts and protecting Đerdap reservoir on the Danube from filling. After the dam had been built, the lake was filled with water in 1975, while the decision on its water supplying purpose was made in 1978. By constructing "water plant" in Majdevo, the system started working in 1984 (Vujović, 1995).

In a long-term plan of water supplying, reservoir "Ćelije" as a source for the regional system should satisfy all the needs of 10 bigger settlements in Pomoravlje (Ražanj, Aleksandrovac, Varvarin, Vrnjačka Spa, Kruševac, Trstenik, Ćićevac, Paraćin, Jagodina, Ćuprija), which, according to the data from Water Management basis of Serbia for 2021 amount to totally $283.4 x$ $10^{6} \mathrm{~m}^{3}$ /year. $\left(173.7 \times 10^{6} \mathrm{~m}^{3} /\right.$ year of quality water and $128 \times 10^{6} \mathrm{~m}^{3} /$ year of industrial water). Although it was foreseen that after the construction of the reservoir "Ćelije" this project will be realized shortly, as of 2014, water from this reservoir supplies only the territory of the municipality of Kruševac, namely the centre of the town and 70 rural settlements. In other settlements, water supplying is done from local water supply in Ribare, from village water supplies in Grkljane and Lomnica, while 27 rural settlements do not have any organized water supplying. In the following period it is planned to connect 20 more settlements to the water system "Ćelije", while 10 more villages under the mountain of Jastrebac would still be supplied with the water from rural water supplying (Просторни план Града Крушевца, 2011).

In a long-term plan of water supplying, all the settlements on the territory of Kruševac, as well as industrial plants, will be supplied with water exclusively from surface water course, that is, from the reservoir "Ćelije" on the river of Rasina (Водопривредна основа Републике Србије, 2001). 
According to the basis of long-term water supplying in Serbia, norms of water consumption are defined and they should be provided. According to previous studies, those norms varied from $580 \mathrm{l} / \mathrm{in}$./ day in 2010 to 600 1/in./day, as it is supposed to be necessary in 2021 (Гавриловић и Дукић, 2014). Prognosed norms of water consumption are defined on the basis of tendencies of demographic, socio-economic and communal development.

Water management basis of Serbia (2001) defines water consumption of $500 \mathrm{l}$ /in./day for rural, and $600 \mathrm{l}$ /in./day for urban settlements. Considering the fact that by the end of the $20^{\text {th }}$ and the beginning of the $21^{\text {st }}$ century there was a tendency of decrease in the number of inhabitants, as well as that industrial production reflects either stagnation or negative trend, for the analysis of water consumption on the territory of Kruševac in the period from 2011 to 2021 a norm of water consumption is adopted. It goes from 350380 1/in./ day in rural areas, to 580-620 1/in./day in the town. (Radović et al., 2000). On the basis of these norms, water consumption and the number of inhabitants for 2011, as well as the estimated number of inhabitants for 2021, values of necessary water capacity for the analyzed territory were obtained. They are given in Table 2 .

Table 2 - The needed capacities of waterworks in the settlements of Kruševac in 2011 and 2021

\begin{tabular}{|l|c|c|c|c|}
\hline \multirow{2}{*}{ Settlements } & \multicolumn{2}{|c|}{2011} & \multicolumn{2}{c|}{2021} \\
\cline { 2 - 5 } & $\begin{array}{c}\text { Number of } \\
\text { inhabitants }\end{array}$ & $\begin{array}{c}\text { Average } \\
\text { capacity } \\
\text { needed (1/s) }\end{array}$ & $\begin{array}{c}\text { Number of } \\
\text { inhabitants }\end{array}$ & $\begin{array}{c}\text { Average capacity } \\
\text { needed (1/s) }\end{array}$ \\
\hline Kruševac- town & 58,745 & 394.35 & 59,430 & 419.59 \\
\hline $\begin{array}{l}\text { Other } \\
\text { settlements }\end{array}$ & 70,007 & 283.58 & 77,107 & 347.19 \\
\hline Total: & 128,752 & 677.93 & 136,537 & 766.78 \\
\hline
\end{tabular}

Source: Попис становништва, домаћинстава и станова 2011. године у Републици Србији. Упоредни преглед броја становника 1948, 1953, 1961, 1971, 1981, 1991, 2002, 2011. године, ккњига 20, Републички завод за статистику, Београд, 2014; Просторни план Града Крушевца, 2011.

On the basis of these data we can conclude that the number of inhabitants on the territory of the town of Kruševac in the period between censuses will be higher for $6.05 \%$, so waterworks capacity should be increased for about $13 \%$ by 2021 . 
These data on average capacity of waterworks were obtained on the basis of estimate of water consumption by the population in urban and rural environments and do not serve and cannot serve as a means of planning construction of waterworks system but they can serve as an indicator of the needed amounts of water, as well as to show where the needs for water are headed in relation to demographic changes in the town of Kruševac.

Long-term sustainable water supplying on the territory of Kruševac will primarily depend on the quantity and quality of their spatial arrangement. To dispose of these available resources in an adequate manner in accordance with the principles of integral development, it is necessary to carry out the following measures defined by the Strategy of water management on the territory of Serbia (2015): increasing the degree of extension of public waterworks systems; improvement of the system of public water supplying (providing a stable water supplying with the water of demanded quality, with decreasing the risk of interruption in water supplying in emergency conditions); decreasing water losses in waterworks systems; rational water usage (establishing economic price of water and education of the population on the necessity of rational water consumption); protection of the springs used for water supplying or could have such a purpose in the future.

Except for water supply, surface waters on the territory of Kruševac can be used for hydro-energetic purposes.

There are no hydro power plants on the territory of Kruševac, which does not imply that there is no potential, nor defined potential location for the construction of so-called mini hydro power plants. As early as during 1980s there was an idea for constructing such power plants on smaller water courses in Serbia, so as to exploit their energy potential. Cadastre of mini hydro power plants (MHPP) in 1987 determined 856 potential locations for the construction of MHPP of total power of $450 \mathrm{MW}$, with the production of 1,590 GWh/year (www.srbijavode.rs).

There are six defined locations on the territory of Kruševac where mini hydropower plants could be built. Two of them are located in the basin of the Južna Morava, that is, the Ribarska river, whereas four of them are in the basin of the Rasina. The above mentioned potential hydropower plants would have installed capacity power from 0.1 MW (Jašica, the Jablanica river) to $0.245 \mathrm{MW}$ (Vita Kosa, the Lomnička river) and as such they would belong to the category of so-called mini hydropower plants. Hydropower plant "Ćelije" would belong to the group of mini hydropower plants, with installed capacity power of 3.8 MW (Sandić and Pašić, 2000). 
To adequately exploit the aforementioned hydro-energetic potential, it is necessary to analyze potential changes in water regime of the said courses in detail, as well as to analyze potential changes in water quality and their natural and anthropogenic environment. In such a way, the possibility of construction and cost-effectiveness of the existence of the said mini hydro power plants will be either affirmed or denied.

Table 3 - Locations of possible construction of mini hydro power plants on the rivers of Kruševac

\begin{tabular}{|l|l|l|c|c|c|}
\hline $\begin{array}{l}\text { Name of } \\
\text { MHPP }\end{array}$ & Basin & River & $\begin{array}{c}\text { Discharge } \\
\left(\mathbf{m}^{\mathbf{3}} \mathbf{s}\right)\end{array}$ & $\begin{array}{c}\text { Drop } \\
(\mathbf{m})\end{array}$ & $\begin{array}{c}\text { Power } \\
(\mathbf{k W})\end{array}$ \\
\hline Jašice & Južna Morava & Ribarska, Srndaljska & 0.295 & 108.2 & 240 \\
\hline $\begin{array}{l}\text { Vučja } \\
\text { rupa }\end{array}$ & Južna Morava & Ribarska, Srndaljska & 0.216 & 96.2 & 150 \\
\hline Rilička & Rasina & Rilička & 0.206 & 78.3 & 125 \\
\hline $\begin{array}{l}\text { Vita } \\
\text { Kosa }\end{array}$ & Rasina & Lomnička & 0.389 & 84.6 & 245 \\
\hline Jašica & Rasina & $\begin{array}{l}\text { Jablanica, Mala I } \\
\text { Velika }\end{array}$ & 0.252 & 51 & 100 \\
\hline Ćelije & Rasina & Rasina & 10 & 43 & 3,800 \\
\hline
\end{tabular}

Source: Vujović, 1995.

Waters in surface courses on the territory of Kruševac are heavily burdened with organic compounds which originate from waste waters from the settlements. Those waste waters are let into water courses with no purifications. All the waste waters of Kruševac canalization are let into the Zapadna Morava with no previous purification. Since there are waters from production process in industrial plants among these waters, the Zapadna Morava is subjected to both biological and chemical pollution, which especially influences preservation of its eco-system.

The beginning of the construction of canalization network in Kruševac concurs with the beginning of the construction of waterworks network. The first collector was built in 1958, and waste waters were let into the Zapadna Morava without any previous purification. At the end of the 1980s construction of the mutual plant for purification of the waste waters of the town started, but only pump station has been built so far out of all the planned buildings. Canalization system is mostly developed on the territory of the town settlement, while few rural settlements only partially constructed ca- 
nalization network. Canalization system of Kruševac, apart from the town itself, consists of the following suburbian settlements: Bivolje, Lazarica, Malo Golovode, Čitluk, Mudrakovac, partially Pakašnica and Begovo Brdo. In rural areas of the municipality, canalization was partially constructed in Veliki Šiljegovac, Jasika and Ribarska spa.

Only 13 settlements on the territory of Kruševac have constructed both functional waterworks and canalization network, while almost one third of all the settlements is still without waterworks and canalization. The fact that 57 settlements of the municipality of Kruševac have waterworks network, but do not have canalization network shows how rudimentary canalization network is (Просторни план Града Крушевца, 2011).

Analysis of the quality of ground waters in the alluvium of the Zapadna Morava shows that the quality of these waters is not on a satisfactory level, because in these locations we can observe the presence of coliform bacteria and aerobic mesophilic bacteria, as well as higher levels of iron, manganese and nitrates (Стричевић, 2015).

Apart from monitoring the quality of surface and ground waters, continuous control of drinking water from the town's waterworks is of the highest importance for water supplying of the population.

Table 4 - Results of analyzing of bacteriologic potability of drinking water from the town's waterworks Kruševac (2010-2014)

\begin{tabular}{|c|c|c|c|c|}
\hline \multirow{2}{*}{ Year } & \multirow{2}{*}{$\begin{array}{c}\text { Number of } \\
\text { samples taken }\end{array}$} & \multicolumn{2}{|c|}{ Defective } & \multirow{2}{*}{ The cause of defectiveness } \\
\hline & & Number & $\%$ & \\
\hline 2010 & 2,259 & 7 & 0.31 & $\begin{array}{l}\text { Slaughter industry; } \\
\text { Fecal pollution }\end{array}$ \\
\hline 2011 & 2,219 & 6 & 0.27 & $\begin{array}{l}\text { Slaughter industry; } \\
\text { Fecal pollution }\end{array}$ \\
\hline 2012 & 2,442 & 3 & 0.12 & $\begin{array}{l}\text { Slaughter industry; } \\
\text { Fecal pollution }\end{array}$ \\
\hline 2013 & 2,325 & 3 & 0.13 & $\begin{array}{l}\text { Slaughter industry; } \\
\text { Fecal pollution }\end{array}$ \\
\hline 2014 & 2,380 & 0 & - & - \\
\hline Total: & 11,625 & 19 & 0.16 & - \\
\hline
\end{tabular}

Source: Dokumentacija Zavoda za zaštitu zdravlja, Kruševac 
Water of the town's waterworks in Kruševac were sampled 11,625 times in total in the period from 2010 to 2014. Bacteriologic defectiveness was determined in 19 samples, and every time the cause was fecal pollution. From physico-chemical aspect, $1.06 \%$ of all the samples were defective, and the causes were turbidity and presence of iron and manganese. In the period observed, the most defective samples appeared in 2010, while sampling in 2014 showed that the water from the town's waterworks was absolutely clean and safe for usage, because all the samples examined were potable both from bacteriological and physico-chemical aspect.

Table 5 - Results of analysing physic-chemical potability of drinking water the town's waterworks Kruševac (2010-2014)

\begin{tabular}{|c|c|c|c|c|}
\hline \multirow{2}{*}{ Year } & \multirow{2}{*}{$\begin{array}{c}\text { Number of } \\
\text { samples taken }\end{array}$} & \multicolumn{2}{|c|}{ Defective } & \multirow{2}{*}{ The cause of defectiveness } \\
\cline { 3 - 4 } & Number & $\%$ & \\
\hline 2010 & 2,259 & 68 & 3.01 & turbidity, Fe, Mn \\
\hline 2011 & 2,219 & 10 & 0.45 & turbidity, Fe, Mn \\
\hline 2012 & 2,442 & 44 & 1.80 & turbidity, Fe, Mn \\
\hline 2013 & 2,325 & 1 & 0.04 & turbidity, Fe, Mn \\
\hline 2014 & 2,380 & 0 & - & - \\
\hline Total: & 11,625 & 123 & 1.06 & - \\
\hline
\end{tabular}

Source: Dokumentacija Zavoda za zaštitu zdravlja, Kruševac

Beside usage and protection of waters from harmful effects, a big challenge in water management is protection of settlements and agricultural land from flooding caused by water effusion of the main course of the Zapadna Morava and its torrential tributaries. Last great floods which hit this region, as well as the whole of Serbia in 2014 imply that it is necessary to carry out extensive anti-erosive works in the whole basin, as well as reconstruction of the existing and construction of new embankments in the whole basin.

On the territory of Kruševac, in the valleys of the Zapadna Morava and Rasina, there are embankments the basic purpose of which is protection of the settlements and agricultural surfaces from flooding. Total length of all the embankments is $12.6 \mathrm{~km}$, but only $5.9 \mathrm{~km}$ serves their purpose in quality, while $7.5 \mathrm{~km}$ of embankments in the valley of the Zapadna Morava is not on a satisfactory level. Because of such a state of the embankments, high waters significantly endanger the right bank of the Zapadna Morava from Čitluk in 
Kruševac, to the confluence of the Rasina in the Zapadna Morava in Bivolje.

To adequately protect settlements and agricultural surfaces from harmful effect of high waters, it is necessary to preliminary estimate the risk from floods, maps of flooding vulnerability, maps of flooding risk and finally a plan of management of risks from flooding, in accordance with the Directive on Floods 2007/60/EK, which resulted from the Directive on waters 2000/60/ЕК (Борисављевић, Костадинов, 2012).

Shown analysis of water resources on the territory of Kruševac, represents basis for long-term planning and management of this important natural resource. Long-term strategic commitments in the concept of integral management of water resources on the territory of the town of Kruševac should comprise the following activities: decrease in specific consumption of water in all the spheres of consumption; planning of urban and industrial development towards available water resources in accordance with water management possibilities and problems of water protection; protection of the existing and potential drinking water springs by measures of spatial planning and economic policy; purification of industrial and communal waste waters before they are let into water courses as the most important measure of ecosystem protection; anti-erosive protection of basins and regulation of rivers by regulating the banks.

\section{Conclusion}

Planned and rational water resource management is one of the most important conditions for their preservation and long-term exploitation.

The town of Kruševac disposes of significant resources of surface and ground waters. Primary aim of water management, related to water supplying of the population, is partially realized by the construction of reservoir "Celije". Up to now this organized water supply has included the urban settlement and 70 rural settlements. By enhancing the capacity of water plant in Majdevo, 10 more settlements should be included in the system in the following period (91 out of 101 in total on the territory of the town). Apart from providing sufficient amounts of quality waters, a big problem in water management on the territory of Kruševac are waste communal waters from the settlements and industrial plants, which significantly influence both direct recipient and water quality. It is necessary to provide adequate purification and drainage of waste waters, which is possible to do by increasing the 
number of households connected to canalization network and the amount of communal and industrial waste waters which are purified adequately, as well as by constructing new plants and reconstructing the existing ones.

The above mentioned problems related to usage, preserving and development of water resources on the territory of Kruševac can be primarily solved by adopting adequate legal regulative, its realization and constant education of the population on the way of water usage, savings and protection. Integral water management consolidates natural system which defines available water resources and their quality, as well as a social component which implies the influence of human factor, which determines the usage of water resources, waste waters production and pollution of water resources (Knežević, 2005).

Water resources represent a good basis for social and economic development of Kruševac, but the plan for their exploitation has to be rational, precisely defined with clear realization possibilities. Unrealistic expectations, burdened with administrative and financial problems, ballast project realization, and complicate life for the population. Water resources are a renewable source, but it should be rationally exploited and preserved for the future generations.

\section{Acknowledgements}

The paper is the result of the research within the project no. 176008 funded by the Ministry of Education and Science of the Republic of Serbia.

\section{References}

Biswas K. A. (2008): Integrated water resources management: Is it working?, Internacional Journal of Water resources development, Volume 24, issue 1, Routlege, 5-22.

Dokumentacija Zavoda za zaštitu zdravlja, Kruševac.

Gourbesville P. (2008): Challenges for integrated water resources management, Physics and chemistry of the Earth, Volume 33, Issue 5 (Elsevier), 284-289.

Knežević B. (2005): Pristup planiranju integralnog upravljanja vodnim resursima - IWRPM, Vodoprivreda, 37 (216-218), 153-162, UDK: 532.543 .3

Marković P. (2011): Stanje i problemi u oblasti upravljanja vodama na lokalnom nivou, Beograd: Stalna konferencija gradova i opština, Ministarstvo poljoprivrede, šumarstva i vodoprivrede i Institut za vodoprivredu "Jaroslav Černi" (2001). 
Radović S., Kapelan Z., Gligorić I. (2000): Perspektive vodosnabdevanja opština Pomoravskog okruga, Zbornik radova "Vodni resursi sliva Velike Morave i њnjihovo korišćenje”, Beograd: Zadužbina Andrejević, 36-43.

Republički hidrometeorološki zavod Srbije. Hidrološki godišnjaci 1950-2009. Beograd: Republički hidrometeorološki zavod Srbije.

Sandić B., Rašić M. (2000): Hidroenergetski potencijal sliva Velike Morave, Zbornik radova "Vodni resursi sliva Velike Morave i njihovo korišćenje", Beograd: Zadužbina Andrejević, 43-54.

Stojadinović D. (2004): Vodni potencijali kruševačke oblasti. Beograd: Zadužbina Andrejević, 1-88.

Van der Zaag P., SaVenije H.G. H. (2014): Principles of Integrated water resources management. Delfi: Institute for water education.

Vorosmarty, C. J., McIntyre, P. B., Gessner, M. O., Dudgeon, D., Prusevich, A., Green, P., Glidden, S. (2010): Global threats to human water security and river biodiversity. Nature,467(7315), 555-561. doi:10.1038/nature09440

Vujović R. (1995): Vode Srbije, planovi razvoja i neke realizacije u vodoprivredi. Beograd: IRO Građevinska knjiga.

Vučijak B., Cerić A., Silajdžić I., Midžić Kurtagić S. (2011): Voda za život, osnove integralnog upravljanja vodnim resursima, Sarajevo: Institut za hidrotehniku Građevinskog fakulteta.

Zakon o vodama (Službeni glasnik Republike Srbije, br. 30/10, 7.5.2010.)

Борисављевић А. Костадинов С. (2012): Интегрисано управљање речним сливом Јужне Мораве, Гласник Српског географског друштва, 92 (1), 135-150.

Влада Републике Србије, Министарство пољопривреде и заштите животне средине (2015): Стратегија управљања водама на територији Републике Србије - анализе и истраживања. Београд: Влада Републике Србије, Министарство пољопривреде и заштите животне средине.

Водопривредна основа Републике Србије (2001), Београд: Министарство пољопривреде, шумарства и водопривреде и ИнИнститут за водопривреду “Јарослав Черни”.

Гавриловић, Љ., Дукић Д. (2014): Реке Србије. Београд: Завод за уџбенике.

Просторни план Града Крушевца (2011): Дирекција за урбанизам и изградњу Крушевац, ЈП Крушевац. 
Републички завод за статистику (2014). Попис становништва, домаћинстава и станова 2011. у Републици Србији, Упоредни преглед броја становника 1948, 1953,1961, 1971, 1981, 1991, 2002, 2011; књ. 20, Београд: Републички завод за статистику.

Стричевић Љ. (2015): Водни ресурси Расинског округа и њихов утицај на регионални развој. (Необјављена докторска дисертација). Природно - математички факултет. Ниш.

Тодић Д. (2015): Управљање водним ресурсима и европске интеграције Србије, Зборник радова Правног факултета у Нишу, 71, 149-167 